\title{
Evaluation of somatic indexes, hematology and liver histopathology of the fish Labrisomus philippii from San Jorge Bay, northern Chile, as associated with environmental stress
}

Evaluación de índices somáticos, hematológicos e histopatológicos del pez Labrisomus philippii de la bahía San Jorge, norte de Chile, asociados con estrés ambiental

\section{Diana Montenegro ${ }^{1}$ and M. Teresa González ${ }^{1}$}

${ }^{1}$ Instituto de Investigaciones Oceanológicas, Universidad de Antofagasta, Casilla 170, Antofagasta, Chile. dmontenegrov@gmail.com; mtgonzalez@uantof.cl

Resumen.- Se estudió el estado de salud de individuos de Labrisomus philippii que habitan en la bahía San Jorge (norte de Chile), caracterizada por presentar altas concentraciones de metales pesados. Adicionalmente, se determinó las concentraciones de metales en el hígado de los peces. Las capturas se realizaron en dos sitios de la bahía: Club de Yates (CY, $n=26$ ) y El Colorado $(E C, n=33)$, expuesto a elevados y bajos niveles de actividad antropogénica, respectivamente. Los peces fueron capturados mediante buceo apnea e inmediatamente trasladados vivos al laboratorio. Cada pez fue medido (longitud total) y pesado (peso total, eviscerado, hígado y gónadas). De cada ejemplar se obtuvo una muestra de sangre obtenida en la región cardiaca. Se determinó el factor de condición $(\mathrm{FC})$, índice hepatosomático $(\mathrm{IH})$, índice gonadosomático (IGS) y parámetros hematológicos (recuento de leucocitos, monocitos y granulocitos). Adicionalmente, se realizó un análisis histológico del hígado de cada ejemplar. La longitud de los peces no se correlacionó con el IH y FC. No hubo diferencias significativas en el FC e IH entre sexos. Los peces del CY mostraron mayores IH y FC. La longitud de los peces se correlacionó positivamente con el número de linfocitos, y negativamente con los granulocitos, mientras los monocitos no se correlacionaron con la longitud de los peces. Las lesiones más frecuentes del hígado fueron degeneración vacuolar $(62 \%$ CY y 30\% EC) y esteatosis ( $23 \%$ CY y $17 \%$ EC); seguida de necrosis, autolisis, y fibrosis. Los resultados sugieren que las lesiones registradas en los peces capturados en bahía San Jorge, y especialmente en los peces de CY, podrían estar asociadas con contaminación por metales pesados.

Palabras clave: Labrisomidae, estado de salud, Océano Pacífico, metales pesados

Abstract. - The health condition of Labrisomus philippii specimens inhabiting San Jorge Bay (northern Chile) which is characterized by high heavy metal contents was studied. Additionally, heavy metals concentrations in fish livers were determined. Fish were captured through apnea diving, from two sites: Club Yates $(\mathrm{CY}, \mathrm{n}=26)$ and El Colorado Beach (EC, $n=33$ ) exposed to high and low levels of anthropogenic activities respectively. Live specimens were transported to the laboratory where macroscopic observations were carried out. Each fish was measured (total length) and weighed (total, liver and gonads weights). Blood samples were obtained from the cardiac region of each specimen. Condition factor (CF), hepatosomatic (HI) and gonadosomatic (GSI) indices, and hematological parameters (counts of lymphocytes, granulocytes ad monocytes) were determined. Fish livers were histologically analyzed. Fish size was not correlated with $\mathrm{HI}$ and CF. There were not significant differences in CF and HI between fish sexes. Fish from the $\mathrm{CY}$ site showed higher $\mathrm{HI}$ and CF. Fish size was positively correlated with the number of lymphocytes, and negatively correlated with granulocytes, whereas there was no correlation between fish size and number of monocytes. The most frequent liver lesions were vacuolar degeneration $(62 \% \mathrm{CY}$ and $30 \% \mathrm{EC})$ and steatosis ( $23 \% \mathrm{CY}$ and $17 \% \mathrm{EC})$; followed by necrosis, autolysis, and fibrosis. Our results suggest that the impairment health of individuals L. philippii in San Jorge Bay, and especially in those specimens living in CY, might be associated with metal pollution.

Key words: Labrisomidae, health status, Pacific Ocean, heavy metals 


\section{INTRODUCTION}

The biological indicator approach can be an effective technique to assess the integrative effects of stress on fish, as well as being a tool to obtain biological information in a system and could be used to manage contaminated sites (Adams et al. 1989, Pastor et al. 2003). Most commonly used bioindicators are corporal indices such as condition factor (CF), gonadosomatic index (GSI) and hepatosomatic index (HI) (Vives et al. 2004, Bastardo et al. 2006). CF is an index reflecting interactions between biotic and abiotic factors in the physiological condition of a fish (Lizama \& Ambrosio 2002). However, organosomatic indices may provide more specific information related to the function of the selected organ (Martin-Diaz et al. 2005). In the case of HI, it is widely used due to its association with seasonal changes; nutritional status, parasite infections and it even may be associated with an increased capacity to metabolize xenobiotics, which could be considered an adaptation to the presence of pollution (Heath 1995).

The histopathological alterations allow for the identification of organs and cells that have been affected in vivo. These changes also demonstrate that in fishes inhabiting polluted areas, important histopathological changes are produced mainly in the liver and kidneys, organs that are involved in the detoxification and that are susceptible to toxics (Auro de Ocampo \& Ocampo 1999). Similarly, variations in hematological parameters such as an increase in the number of leucocytes are a normal reaction against attacks of foreign substances, which can alter the normal physiological function in fish (Nussey et al. 1995).

San Jorge Bay (Antofagasta) is located at $23.5^{\circ} \mathrm{S}$, on the boundary of the Atacama Desert. At this latitude, the linearity of the northern Chilean coast is interrupted by two bay systems: one oriented toward the north (Mejillones) and another oriented toward the south (San Jorge). Local oceanographic conditions are controlled by the influence of the Humboldt Current, which is characterized by permanent upwelling cells (Strub et al. 1998). This area borders one of the world's most arid regions, and continental input to the ocean is restricted to minimal atmospheric transport of lithogenic particles (Vargas et al. 2004). Therefore, upwelling seems to be one of the most important natural processes influencing the chemical composition of the water column and bottom sediments (Valdés et al. 2010).
In San Jorge Bay, particularly at Club de Yates-Fishing port site, there are areas where anthropogenic activities (loading ships with copper, lead and other products) have been common since 1943. Additionally, the bay has three oil-loading terminals and one effluent for the discharge of domestic waters after a secondary treatment (Valdés et al. 2010). Consequently, organisms inhabiting this area could be exposed to environmental stress.

Some studies have reported high concentrations of $\mathrm{Cu}, \mathrm{Pb}$ and $\mathrm{Zn}$ in the water column and in the tissues of bivalves in sites within San Jorge Bay (Salamanca et al. 2000, 2004). However, in this geographical area as well as along the Chilean coast, there are scarce studies evaluating pollution effects on the health of marine organisms (George-Nascimento et al. 2000, Riveros et al. 2002, 2003, Leonardi et al. 2009a, b).

Marty et al. (1999) suggest that rocky fishes remain in the same place for several years, and can be considered as an ideal species to evaluate the effects of stress in some areas. Labrisomus philippii (Steindachner, 1866) is a benthic-littoral fish species distributed in the southeastern Pacific from Paita, Peru $\left(7^{\circ} \mathrm{S}\right)$ to Coquimbo, Chile $\left(30^{\circ} \mathrm{S}\right)$; it is a sedentary species that lives in shallow waters of approximately 5 to $6 \mathrm{~m}$ depth (Vélez 1981). Therefore, this species could be appropriate for pollution monitoring studies.

The aim of this study was to describe the health condition, measured through liver histology, hematology, corporal indices (CF, GSI, HI) and concentrations of heavy metals in the liver of the fish Labrisomus philippii inhabiting San Jorge Bay, northern Chile.

\section{Materials AND METHODS}

\section{SAMPLING}

During October and November, 2006, 59 specimens of Labrisomus philippii were captured through apnea diving at 2 sites in San Jorge Bay (Fig. 1). Twenty six specimens were captured in Club de Yates-Fishing port (CY: 233' 3 'S; $70^{\circ} 24^{\prime} \mathrm{W}$ ), a site exposed to anthropogenic activities; and 33 specimens were captured in El Colorado Beach (EC: $23^{\circ} 30^{\prime} \mathrm{S} ; 70^{\circ} 31^{\prime} \mathrm{W}$ ), a site located in the northwest of the bay, where anthropogenic activities are scarce or absent.

\section{SOMATIC INDICES}

Specimens captured were immediately transported alive to the laboratory at the University of Antofagasta where 


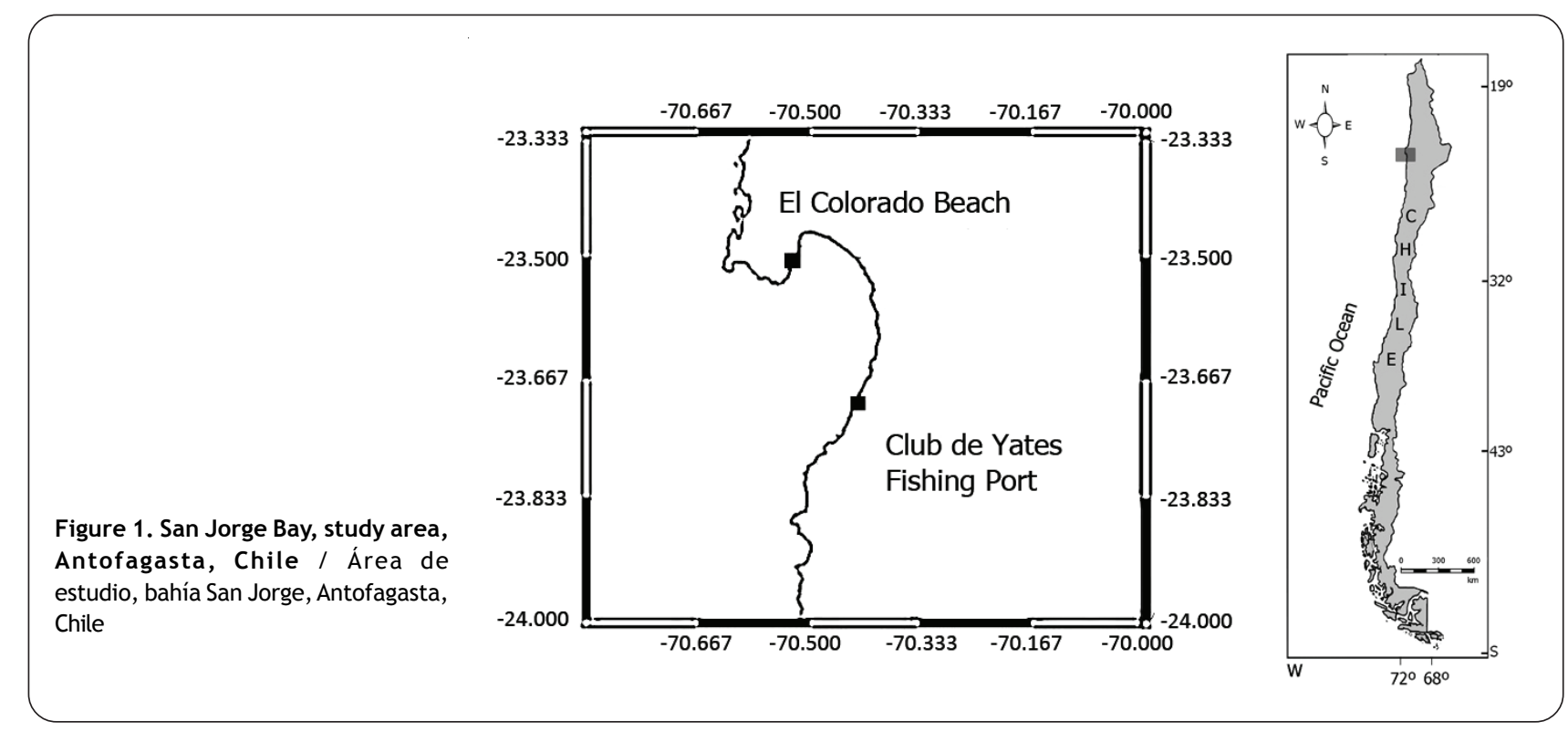

macroscopic observations were recorded, afterward each fish was measured (total length) with an ichthyometer $( \pm$ $1 \mathrm{~cm}$ precision), weighed (total weight, visceral weight, liver weight, gonad weights) using an analytic balance $( \pm 0.01 \mathrm{~g})$. Then, the hepatosomatic index (HI), gonadosomatic index (GSI), and condition factor (CF) expressed in percentage were calculated according to Nikolsky (1963).

\section{BLOOD SAMPLES}

Syringes $(0.2 \mathrm{ml})$ were used to obtain blood from the cardiac region of the fish. Smears were prepared, and stained with May Grunwald-Giemsa (Moller \& Anders 1986). Lymphocytes, granulocytes and monocytes were counted up to the first 100 cells under an optical microscopic and expressed as percentages, following Orun \& Erdemil (2002).

\section{Histology}

Tissues were preserved in Davidson's solution (Bancroft $\&$ Stevens 1990). Each organ was sectioned at $5 \mu \mathrm{m}$ with a Minot microtome, and stained with hematoxylin-eosin. The samples were revised according to Hibiya (1982) and Stevens et al. (2003).

\section{CONCENTRATION OF HEAVY METALS}

Liver composite samples of approximately $5 \mathrm{~g}$ were weighed employing a Sartorius 4503 analytical balance. Samples were homogenized to a fine powder with a porcelain pestle and mortar and digested in concentrated $\mathrm{HNO}_{3}$ in a Teflon bomb, dried using LYOVAC GT2, and pulverized using Planetary Mill Pulverisette 5. Metal concentrations were determinated using a flame atomic absorption spectrophotometer (Shimadu AA-6300 Model). A standard reference material, DORM-3 (dogfish) National Research Council of Canada, was used (Román et al. 2003). The metal concentrations were expressed in $\mathrm{mg} \mathrm{kg}^{-1}$ tissue dry weight ${ }^{-1}$ (ISP 1998).

\section{Statistical ANaLYSES}

Spearman correlation analyses were used to evaluate the possible association between fish size with corporal indices and hematological parameters. Also, this test was used to evaluate the association between the number of liver lesions and fish size. U-Mann Whitney tests were used to evaluate the possible differences in fish sizes, hepatosomatic index (HI), female gonodosomatic index (FGSI) and male gonodosomatic index (MGSI), female condition factor (FCF), male condition factor (MCF) and hematological parameters (number of lymphocytes, monocytes and granulocytes) between fish sexes. The same test was used to evaluate differences in fish corporal indices and their hematological parameters between sites (Zar 1999). The prevalence of the different liver lesions between fish sex and between sites were evaluated using G-test for independence in $\mathrm{R}^{*} \mathrm{C}$ Tables (Zar 1999). All analyses were performed using the software Statistica 6.0. 


\section{RESULTS}

Fish size varied between 17.5 and $28.5 \mathrm{~cm}$ TL. Mean fish size, body weight, liver weight, gonad weight, corporal indices (HI, GSI, CF), and number of analyzed fish in each site are given in Table 1. There were significant differences in fish size between sexes $(\mathrm{U}=641, P=0.003)$, where the examined males were the largest. Also, fish sizes varied significantly between sites $(\mathrm{U}=980.5, P=0.002)$, where those from $\mathrm{CY}$ were larger.

\section{BODY INDICES AND HEMATOLOGICAL PARAMETERS}

Fish size was not correlated with $\mathrm{HI}(\mathrm{r}=0.142 ; P=0.282)$, GSI $(\mathrm{r}=-0.198 ; P=0.133)$ and $\mathrm{CF}(\mathrm{r}=0.227 ; P=0.084)$. There were not significant differences in $\mathrm{CF}(\mathrm{U}=747 ; P=$ $0.160)$ and $\mathrm{HI}(\mathrm{U}=870 ; P=0.654)$ between fish sexes. The GSI of males and females did not show significant differences between sites, whereas the $\mathrm{HI}$ and $\mathrm{CF}$ showed significant differences between sites, being higher in fish from the CY site (Table 1).

The number of lymphocytes was positively correlated with fish size $(\mathrm{r}=0.45, \mathrm{n}=30, P=0.02)$, the quantity of granulocytes was negatively correlated with fish size $(\mathrm{r}=$ $-0.44, \mathrm{n}=30, P=0.01$ ), whereas the number of monocytes was not correlated with fish size $(\mathrm{r}=-0.28, \mathrm{n}=30, P=$
0.14). Consequently, the mean number of lymphocytes was significantly higher in fish from site $\mathrm{CY}$; whereas monocytes and granulocytes in fish from $\mathrm{CY}$ were significantly lower than fish from site EC (Table 1).

\section{Histological analyses}

Of the total examined specimens, $73 \%$ of fish ( $88 \%$ from site $\mathrm{CY}$ and $58 \%$ from site EC) showed evident lesions in their liver (Fig. 2). The characteristics of a healthy liver versus a liver with lesions are showed in Figures 3, 4, and 5 , respectively. The most frequent lesions were vacuolar degeneration (VD): $62 \%$ prevalence in $\mathrm{CY}$ versus $30 \%$ in EC; and steatosis (S): $23 \%$ in CY and $17 \%$ in EC; followed by necrosis (N): $12 \% \mathrm{CY}$ and $7 \% \mathrm{EC}$, autolysis (A): $15 \%$ $\mathrm{CY}$ and $4 \% \mathrm{EC}$, and fibrosis (Fi): $12 \% \mathrm{CY}$ and $0 \% \mathrm{EC}$. Thus, excluding this last lesion from the statistical analyses, the prevalence of different types of lesions (VD, $\mathrm{S}, \mathrm{N}, \mathrm{A}, \mathrm{Fi}$ ) and no lesions (NL) did not vary significantly between sites $(\mathrm{G}=8.83, \mathrm{df}=4, P=0.065)$, neither between fish sexes $(\mathrm{G}=5.06, \mathrm{df}=4, P=0.28)$. The number of lesions co-occurring in the same fish did not vary significantly between sites $(\mathrm{G}=1.8, \mathrm{df}=2, P=0.4)$, and it was not significantly correlated with fish size in both sites (CY: $\mathrm{r}=0.009, \mathrm{n}=26, P=0.96$ and EC: $\mathrm{r}=0.37, \mathrm{n}=22$, $P=0.08)$.

Table 1. Mean values $\left(X_{ \pm} S D\right)$ of corporal indices and haematological parameters of Labrisomus philippii from CY and EC in San Jorge Bay. HI: hepatosomatic index; MCF: Male condition factor; FCF: female condition factor; MGSI: male gonadosomatic index and FGSI: female gonadosomatic index / Valores promedios $(\mathrm{X} \pm \mathrm{DE})$ de índices corporales y parámetros hematológicos de Labrisomus philippii provenientes de CY y EC en la bahía San Jorge. HI: índice hepatosomático; MCF: factor de condición para machos; FCF: factor de condición para hembras; MGI: índice gonadosomático de los machos y FGI: índice gonadosomático de las hembras

\begin{tabular}{lclll}
\hline \multicolumn{1}{c}{ Sites } & \multicolumn{2}{c}{ CY } & \multicolumn{2}{c}{ EC } \\
\hline Male size $(\mathrm{cm})^{*}$ & $24.00 \pm 2.36$ & $(\mathrm{n}=18)$ & $21.80 \pm 3.31$ & $(\mathrm{n}=13)$ \\
Female size $(\mathrm{cm})$ & $21.41 \pm 1.37$ & $(\mathrm{n}=8)$ & $21.01 \pm 1.50$ & $(\mathrm{n}=20)$ \\
Male weight $(\mathrm{g}) *$ & $198.91 \pm 65.88$ & $(\mathrm{n}=18)$ & $149.87 \pm 79.90$ & $(\mathrm{n}=13)$ \\
Female weight $(\mathrm{g}) *$ & $145.27 \pm 24.34$ & $(\mathrm{n}=8)$ & $125.33 \pm 30.21$ & $(\mathrm{n}=20)$ \\
Liver weight $(\mathrm{g}) *$ & $2.93 \pm 1.51$ & $(\mathrm{n}=26)$ & $1.65 \pm 0.80$ & $(\mathrm{n}=33)$ \\
HI* & $1.69 \pm 0.51$ & $(\mathrm{n}=26)$ & $1.34 \pm 0.41$ & $(\mathrm{n}=33)$ \\
MCF* & $1.31 \pm 0.09$ & $(\mathrm{n}=18)$ & $1.24 \pm 0.08$ & $(\mathrm{n}=13)$ \\
FCF** & $1.35 \pm 0.09$ & $(\mathrm{n}=8)$ & $1.21 \pm 0.09$ & $(\mathrm{n}=20)$ \\
MGSI & $0.31 \pm 0.12$ & $(\mathrm{n}=18)$ & $0.25 \pm 0.23$ & $(\mathrm{n}=13)$ \\
FGSI & $3.27 \pm 1.24$ & $(\mathrm{n}=8)$ & $2.43 \pm 1.60$ & $(\mathrm{n}=20)$ \\
Lynphocytes $(\%)^{* *}$ & $79.50 \pm 3.47$ & $(\mathrm{n}=15)$ & $57.40 \pm 2.07$ & $(\mathrm{n}=15)$ \\
Monocytes $(\%)^{* *}$ & $16.50 \pm 3.31$ & $(\mathrm{n}=15)$ & $57.40 \pm 2.07$ & $(\mathrm{n}=15)$ \\
Granulocytes $(\%)^{* *}$ & $4.00 \pm 3.15$ & $(\mathrm{n}=15)$ & $14.20 \pm 3.19$ & $(\mathrm{n}=15)$ \\
\hline
\end{tabular}

$*=$ significant differences at $P \leq 0.02 ; * *=$ significant differences at $P<0.001$ 


\section{CONCENTRATION OF HEAVY METALS}

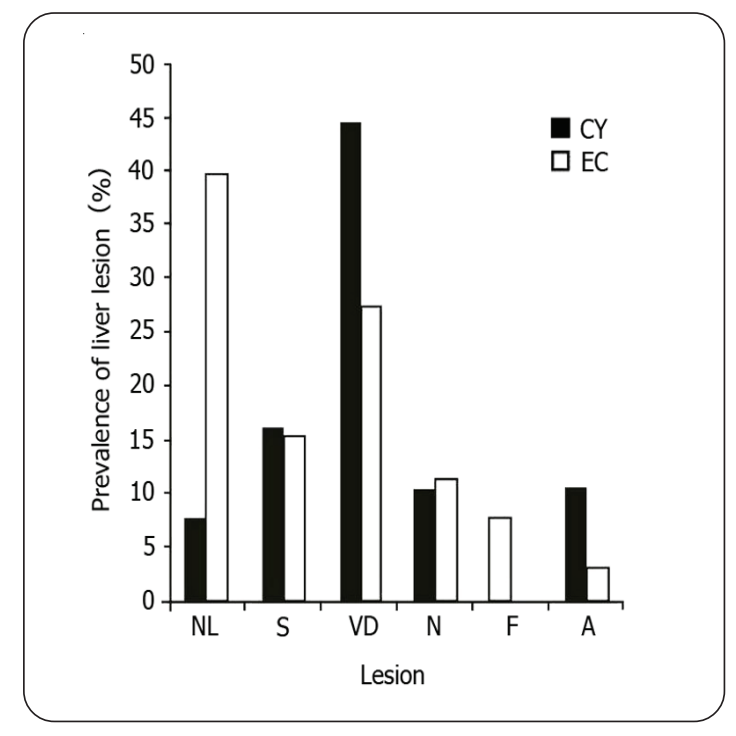

Figure 2. Prevalence of liver lesions observed in Labrisomus philippii individuals in two sites Club de Yates-Fishing port (CY) and El Colorado Beach (EC) from San Jorge Bay. NL: no lesion; S: steatosis; VD: vacuolar degeneration; N: necrosis; Fi: fibrosis; A: autolisis / Prevalencia de las lesiones observadas en el hígado de individuos Labrisomus philippii en el sector Club de YatesPuerto Pesquero (CY) y Playa El Colorado (EC) en la bahía San Jorge. NL: sin lesiones; S: esteatosis; VD: degeneración vacuolar; N: necrosis; Fi: fibrosis; A: autolisis
The heavy metal concentrations were higher in fish livers from CY (Table 2). Arsenic and copper concentrations were higher in fishes from CY (Table 2) and exceeded the maximum accepted values for human consumption (As: 1 ppm and $\mathrm{Cu}: 10 \mathrm{ppm}$ ) by the 'Reglamento Sanitario de los alimentos, Decreto Supremo ${ }^{16}$.

\section{Discussion}

To assess fish health, the bioindicators technique utilizes a suite of biological responses both as integrators of stress effects and sensitive response (early-warning) indicators of existing and past environmental conditions (Adams 1990). Corporal indices have been commonly used for biomonitoring of environmental stress on fish health (Khan \& Payne 1997, George-Nascimento et al. 2000, Schulz \& Martins-Junior 2001, Khallaf et al. 2003). In this study, CF and $\mathrm{HI}$ were significantly higher in fishes from $\mathrm{CY}$ where there are higher anthropogenic activities. These increased HI values cannot be related with fish sex or reproductive processes because the fish samples were collected in the same period. Therefore, higher values of $\mathrm{HI}$ in fish from CY could be related to a higher presence of xenobiotics, but it cannot be disregarded that other factors are involved in $\mathrm{CF}$ and $\mathrm{HI}$ differences. In the case of $\mathrm{HI}$, it is not specific to pollution, and $\mathrm{HI}$ variations between sites could depend on other factors such as nutritional status, and even parasite infections (Heath 1995).

Table 2. Heavy metal concentrations $\left(\mathrm{mg} \mathrm{kg}^{-1}\right)$ in the liver of Labrisomus philippii from two sites in San Jorge Bay. CY: Club de Yates; EC: El Colorado Beach / Concentración de metales pesados $\left(\mathrm{mg} \mathrm{kg}^{-1}\right)$ en hígado de Labrisomus philippii capturados en dos sitios de la bahía San Jorge, CY: Club de Yates; EC: Playa El Colorado

\begin{tabular}{|c|c|c|c|c|}
\hline \multirow{2}{*}{$\begin{array}{l}\text { Heavy metal } \\
\text { concentration }\end{array}$} & \multicolumn{2}{|l|}{$\mathrm{CY}$} & \multicolumn{2}{|l|}{$\mathrm{EC}$} \\
\hline & $\begin{array}{l}\text { With lesion } \\
\quad * * \mathrm{~N}=3\end{array}$ & $\begin{array}{l}\text { No lesion } \\
\quad * \mathrm{~N}=1\end{array}$ & $\begin{array}{l}\text { With lesion } \\
\qquad N=3\end{array}$ & $\begin{array}{c}\text { No lesion } \\
* N=1\end{array}$ \\
\hline As & $4.11+1.47$ & 4.69 & $2.57+0.71$ & 2.05 \\
\hline $\mathrm{Cd}$ & $10.63+0.71$ & 3.59 & $2.53+2.24$ & $<0.08$ \\
\hline $\mathrm{Cu}$ & $29.60+16.55$ & 10.80 & $14.57+4.27$ & 11.00 \\
\hline $\mathrm{Zn}$ & $81.67+5.13$ & 35.00 & $56.00+36.41$ & 16.00 \\
\hline $\mathrm{Pb}$ & $<1$ & $<1$ & $<1$ & $<1$ \\
\hline
\end{tabular}

* One composite sample with 4 livers of L. philippii

** Three composite samples with 6 livers of $L$. philippii

${ }^{1}$ Reglamento sanitario de los alimentos. Decreto supremo n ${ }^{\circ}$ 977/96. Publicado en el Diario Oficial 13 enero 2000. Gobierno de Chile. Chile, 193 pp. <http://www.sernac.cl/sernac2011/descargas/leyes/decreto/ds_977-96_reglamento_alimentos.pdf> 


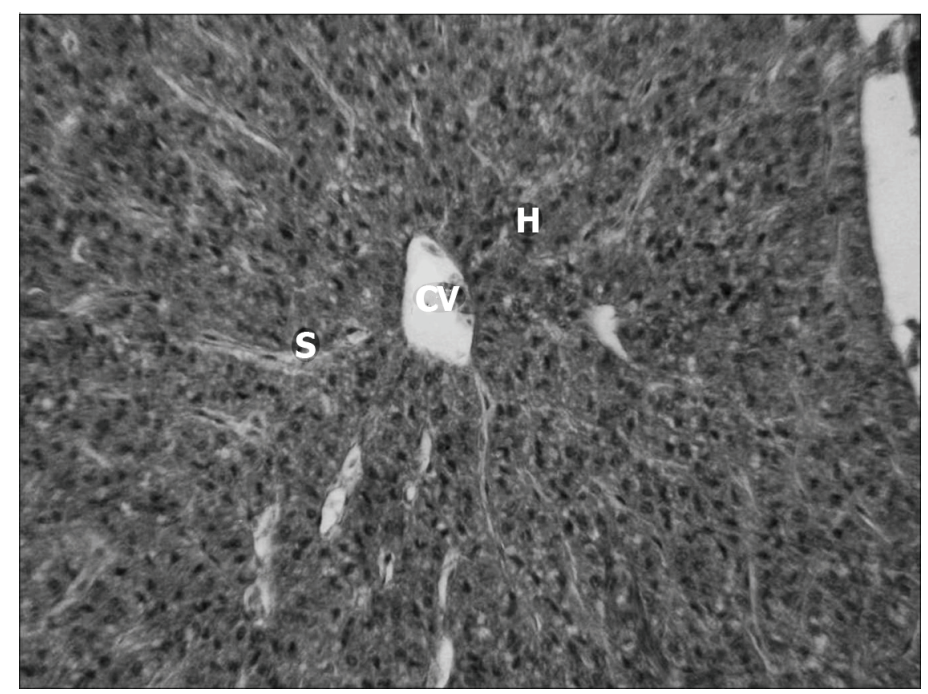

Figure 3. Normal liver of Labrisomus philippii from site EC, San Jorge Bay, Antofagasta. H-E: 40x. CV: central vein; S: sinusoids; $H$ : hepatocyte / Hígado normal de Labrisomus philippii desde el sitio EC, bahía San Jorge, Antofagasta. H-E: 40x. CV: vena central; S: sinusoide; H: hepatocito

Figure 4. Steatosis in the liver of Labrisomus philippii from site CY, San Jorge Bay, Antofagasta. H-E, 40x. CV: central vein; S: sinusoids; $\mathrm{H}$ : hepatocyte / Esteatosis en hígado de Labrisomus philippii del sitio CY, bahía San Jorge, Antofagasta. H-E, 40x. CV: vena central; S: sinusoide; $\mathrm{H}$ : hepatocito
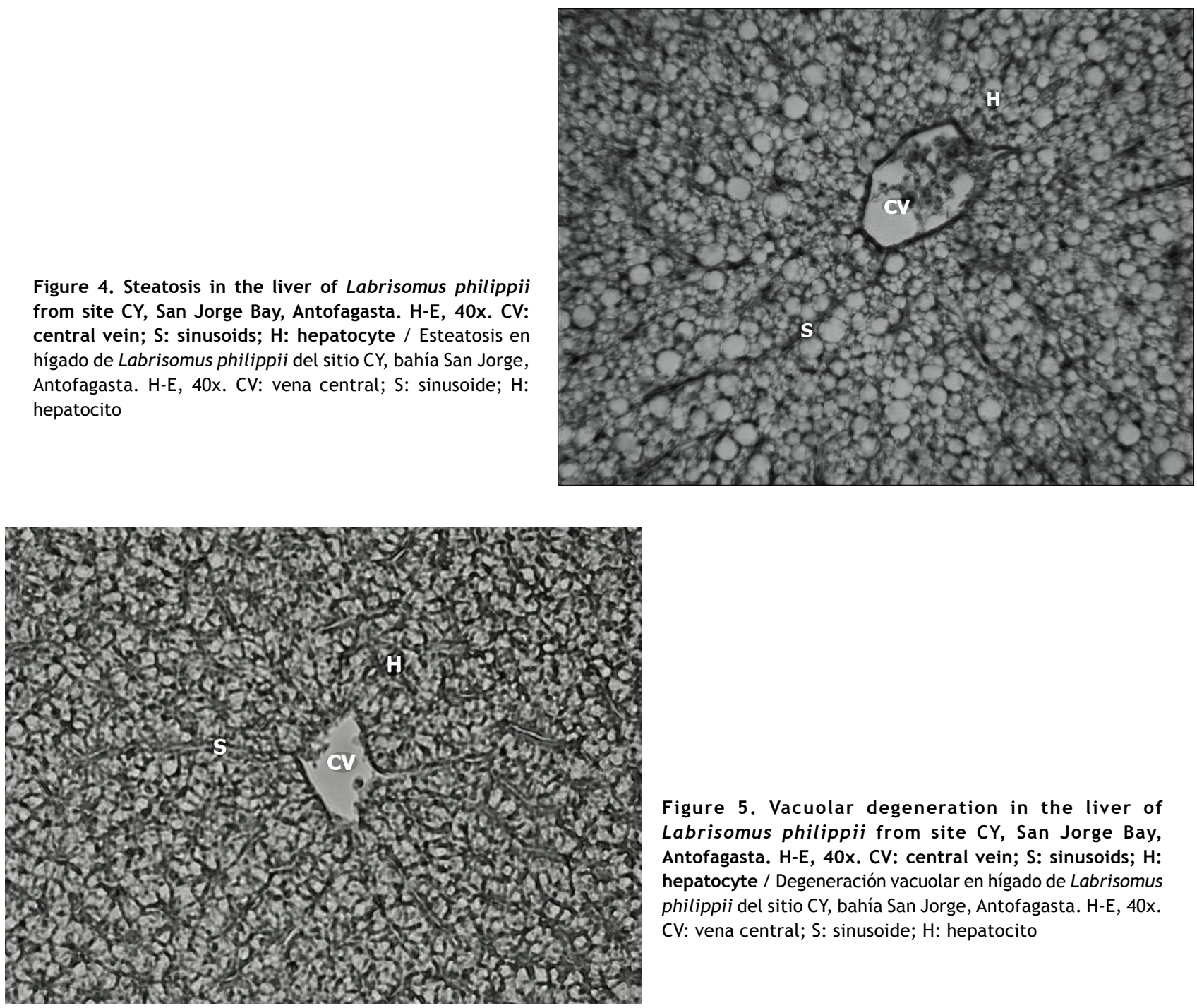

Figure 5. Vacuolar degeneration in the liver of Labrisomus philippii from site CY, San Jorge Bay, Antofagasta. H-E, 40x. CV: central vein; S: sinusoids; H: hepatocyte / Degeneración vacuolar en hígado de Labrisomus philippii del sitio CY, bahía San Jorge, Antofagasta. H-E, 40x. $\mathrm{CV}$ : vena central; S: sinusoide; $\mathrm{H}$ : hepatocito 
Vacuolar degeneration is a morpho-pathological alteration of the gastro-intestinal tract, and it may be associated with toxins and/or infection, which causes significant loss of water and potassium. Steatosis (lipid accumulated in the liver cells) could be present when there is excessive fat to be metabolized, or the lipid function of the liver cells are impaired due to hypoxia, toxic damage or certain infectious diseases (Szende \& Suba 1999). Both vacuolar degeneration and fatty degeneration are reversible injuries, and cells can recover their normal functions (homeostasis) when the stress is removed. However, the recovery of cells will depend on the severity and duration of exposure to stressors. Some authors (Khan 1998, Marty et al. 1998, 1999) have found that these lesions in the liver are associated to hydrocarbons. Other studies have found similar lesions in fishes exposed to cadmium chloride, benzo(a)pyrene, pulp mill drains and domestic drains (George-Nascimento et al. 2000, Pacheco \& Santos 2004), pathogen load (Schwaiger 2001), and even related with fish age (Bastardo et al. 2006). Mohamed (2008) and Costa \& Costa (2008) showed marked histopathological changes in liver, attributed to accumulative heavy metals in the liver.

The kidneys and liver are the main target organs for cadmium, they can store considerable amounts of pollutant, and the latter can allow such pollutants to be redistributed to other organs (Kumar \& Singh 2010). San Jorge Bay is characterized by copper mining activities where high concentrations of copper and cadmium have been recorded in sediments (Valdés et al. 2010). Fishes examined with liver lesions, mainly from $\mathrm{CY}$, presented higher concentration values of $\mathrm{Cu}$ and $\mathrm{Cd}$ in comparison to those without lesions, suggesting that metal concentrations could be one of the causes of liver impairment. However, more studies are necessary to confirm this assumption.

Many studies consider understanding the peripheral blood leukocytes (lymphocytes, monocytes, granulocytes) to be crucial in order to detect stress in fishes since this gives information about the immune system (Olabuenaga 2000). Nussey et al. (1995) reported increased number of lymphocytes and granulocytes (eosinophils) combined with significant decreases in monocytes, which were indicative of changes (infections) that occurred after exposure to copper in Mozambique tilapia (Oreochromis mossambicus). In this study, there were differences in lymphocytes and granulocytes between fish from each site, but these differences can be explained by fish size differences. Only monocyte differences could be explained by site. CY is an area near a fishing port, where anthropogenic activities are common. For a long time, fishing boats have released petroleum into the water, while high hydrocarbon concentrations in the water column as well as in the sediments have been detected in CY (CREA 2005, CONAMA 2007²). In addition, in October 31 of 2005, the Eider vessel underwent an accident, with the consequent oil spill between 'Las Petroleras' beach

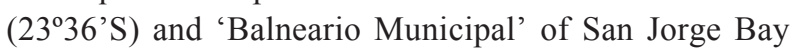
(2340'S) (Garcia-Borboroglu et al. 2008). Other studies have reported high concentrations of $\mathrm{Cu}, \mathrm{Pb}$ and $\mathrm{Zn}$ in the water column and bivalve tissues in an area close to site CY, San Jorge Bay (Salamanca et al. 2000, 2004). Therefore, it is probable that Labrisomus philippii have been exposed for long periods of time to hydrocarbons, and heavy metals, especially $\mathrm{Cu}$ and $\mathrm{Cd}$. Consequently, the impaired health of individuals L. philippii in San Jorge Bay, and especially for those specimens living in CY, might be associated with pollution; but is not denied that other causes may be influencing. Futures studies need to evaluate the use of L. philippii as a bioindicator of environmental quality in San Jorge Bay.

\section{ACKNOWLedgMents}

Authors give thanks to Dr. Oscar Lopez (U. Santo Tomas, Santiago) and we also give thanks to medical technicians Nadia Muñoz for her help in taking blood samples. Finally, we gratefully thank to anonymous reviewers for their suggestions at this manuscript.

\section{LITERATURE CITED}

Adams SM. 1990. Status and use of bioindicators for evaluating effects of chronic stress on fish. American Fisheries Society Symposium 8: 1-8.

Adams SM, KL Shepard, MS Greeley, BD Jimenez, MG Ryon, LR Shugart, J McCarthy \& D Hinton. 1989. The use of bioindicator for assessing the effects of pollutant stress on fish. Marine Environmental Research 28: 459-464.

Auro de Ocampo A \& L Ocampo. 1999. Diagnóstico del estrés en peces. Veterinaria México 30(4): 337-344.

Bancroft JD \& A Stevens. 1990. Theory and practice of histological techniques, 744 pp. Churchill Livingstone, London.

${ }^{2}$ CONAMA. 2007. Levantamiento de información para el control ambiental de la bahía San Jorge, Antofagasta, Chile. Comisión Nacional de Medio Ambiente, Chile. BIP-30059576-0 
Bastardo H, C Scorza \& S Sofia. 2006. Variables hematológicas y bioquímicas en la trucha arcoíris, relacionadas con la condición hepática y la edad. Zootecnia Tropical 24: 1-15.

Costa P \& M Costa. 2008. Biochemical and histopathological endpoints of in vivo cadmium toxicity in Sparus aurata. Ciencias Marinas 34(3): 343-361.

CREA. 2005. Contaminación por hidrocarburos en la zona costera de la ciudad de Antofagasta. Centro regional de Estudios Ambientales, Universidad de Antofagasta. [on line] $<$ www.uantof.cl/crea/INFORMECOLUMNADEAGUA.pdf $>$

Garcia-Borboroglu P, PD Boersma, L Reyes \& E Skewgard. 2008. Petroleum pollution and penguins: marine conservation tools to reduce the problem. In: Hofer T (ed). Marine pollution: New research, pp. 339-356. Nova Science Publishers, New York.

George-Nascimento M, RA Khan, F Garcias, V Lobos, G Muñoz \& V Valdebenito. 2000. Impaired health in Flounder, Paralichthys spp. inhabiting costal Chile. Bulletin of Environmental Contamination and Toxicology 64: 184190.

ISP. 1998. Manual de métodos de análisis físico-químicos de alimentos, agua y suelos, 184 pp. Instituto de Salud Pública, Ministerio de Salud, Santiago de Chile

Heath A. 1995. Water pollution and fish physiology, 359 pp. CRC Press, Boca Ratón.

Hibiya T. 1982. An atlas of fish histology, normal and pathological, 147 pp. Kodansha, Tokyo.

Khallaf E, M Galal \& M Authman. 2003. The biology of Oreochromis niloticus in a polluted Canal. Ecotoxicology 12: 405-416.

Khan RA. 1998. Influence of petroleum at a refinery terminal on feral Winter Flounder, Pleuronectes americanus. Bulletin of Environmental Contamination and Toxicology 61: 770777.

Khan R \& J Payne. 1997. A multidisciplinary approach using several biomarkers, including a parasite, as indicators of pollution: a case history from a paper mill in Newfoundland. Parassitologia 39(3): 183-188.

Kumar P \& A Singh. 2010. Cadmium in fish: an overview. Bulletin of Biosciences 1(1): 41-47.

Leonardi M, E Tarifeño \& J Vera. 2009a. Diseases of the Chilean Flounder, Paralichthys adspersus (Steindachner, 1867), as a Biomarker of Marine Coastal Pollution Near the Itata River (Chile): Part II. Histopathological Lesions. Archives of Environmental Contamination and Toxicology 56: 546-556.

Leonardi M, J Vera, E Tarifeño, M Puchi \& V Morin. 2009b. Vitellogenin of the Chilean flounder Paralichthys adspersus as a biomarker of endocrine disruption along the marine coast of the South Pacific. Part I: induction, purification, and identification. Fish Physiology and Biochemistry 36: 757-765.
Lizama MAP \& AM Ambrosio. 2002. Condition factor in nine species of fish of the Characidae family in the upper Parana River Floodplain, Brazil. Brazilian Journal of Biology 62(1): 113-124.

Martin-Diaz M, S Tuberty, C McKenney, D Sales \& T Del Valls. 2005. Effects of cadmium and zinc on Procambarus clarkii: simulation of the Aznalcollar mining spill. Ciencias Marinas 31(1b): 197-202.

Marty G, M Okihiro \& D Hinton. 1998. Fish histopathology damage assessment after the Exxon Valdez Oil Spill. Technical Services Study Number 2. Final Report, Habitat and Restoration Division, University of California Davis, $176 \mathrm{pp}$.

Marty G, M Okihiro, E Brown, D Hanes \& D Hinton. 1999. Histopathology of adult Pacific herring in Prince William Sound, Alaska, after Exxon Valdez oil spill. Canadian Journal of Fisheries and Aquatic Sciences 56: 419-426.

Miller S \& M Mitchell. 2008. Chapter 4. Ornamental fish. In: Mitchell M \& T Tully Jr. (eds). Manual of exotic pet practice, pp. 39-72. Saunders Elsevier, Saint Louis.

Mohamed F. 2008. Bioaccumulation of selected metals and histopathological alterations in tissues of Oreochromis niloticus and Lates niloticus from Lake Nasser, Egypt. Global Veterinaria 2(4): 205-218.

Moller H \& K Anders. 1986. Diseases and parasites of marine fishes, 365 pp. Verlag Moller, Kiel.

Nikolsky G. 1963. The ecology of fishes, 352 pp. Academic Press, London and New York.

Nussey G, JHJ Van Vuren \& HH Du Preez. 1995. Effect of copper on the differential white blood cell counts of the Mozambique tilapia (Oreochromis mossambicus). Comparative Biochemistry and Physiology 111(C): 381388.

Olabuenaga SE. 2000. Sistema inmune en peces. Gayana 64(2): 205-215.

Orun I \& U Erdemil. 2002. A study on blood parameters of Capoeta trutta (Heckel, 1843). Journal of Biological Sciences 2(8): 508-511.

Pacheco M \& M Santos. 2004. Biotransformation, genotoxic, and histopathological effects of environmental contaminants in European eel (Anguilla anguilla L.). Ecotoxicology and Environmental Safety 53: 331-347.

Pastor J, A Gutierrez-Maroto \& A Hernandez. 2003. Biomarcadores a nivel de una comunidad de pasto y de una población herbácea forrajera para suelos contaminados por cobre. Anales de Biología 25: 103-108.

Riveros A, M Zuñiga, A Hernandez \& A Camaño. 2002. Cellular biomarkers in native and transplanted populations of the mussel Perumytilus purpuratus in the intertidal zones of San Jorge Bay, Antofagasta, Chile. Archives of Environmental Contamination and Toxicology 42: 303-312. 
Riveros A, M Zuñiga \& A Larrain. 2003. Copper metallothionein-like proteins as exposure biomarker in native and transplanted intertidal populations of the mussel Perumytilus purpuratus from San Jorge Bay, Antofagasta, Chile. Bulletin of Environmental Contamination and Toxicology 70: 233-241.

Román D, L Ribera, L Morales, T Avila \& P Cortés. 2003. Determination of trace elements in environmental and biological samples using improved sample introduction in flame atomic absorption spectrometry (HHPN-AAS; HHPN-FF-AAS). International Journal of Environmental Analytical Chemistry 83: 327-341.

Salamanca M, A Camaño, B Jara \& T Rodriguez. 2000. Cu, $\mathrm{Pb}$ and $\mathrm{Zn}$ distribution in nearshore waters in San Jorge Bay, Northern Chile. Gayana 64(2): 195-204.

Salamanca M, B Jara \& T Rodriguez. 2004. Niveles de $\mathrm{Cu}$, $\mathrm{Pb}$ y $\mathrm{Zn}$ en agua y Perumytilus purpuratus en Bahía San Jorge, norte de Chile. Gayana 68(1): 53-62.

Schulz U \& H Martins-Junior. 2001. Astyanax fasciatus as bioindicator of water pollution of Rio dos Sinos, R.S., Brazil. Brazilian Journal of Biology 61(4): 615-622.

Schwaiger J. 2001. Histopathological alterations and parasite infection in fish: indicators of multiple stress factors. Journal of Aquatic Ecosystem Stress and Recovery 8: 231-240.

Stevens A, J Lowe \& B Young. 2003. Wheater histopatología básica. Atlas y texto en color, 304 pp. Elsevier, Barcelona.
Strub P, J Mesias, V Montecinos, J Rutllant \& S Marchant. 1998. Coastal oceanic circulation off western South America. In: A Robinson \& K Birnk (eds). The Sea, pp. 273314. Wiley, New York.

Szende B \& Z Suba. 1999. Introduction to histopathology, 292 pp. Medicina Publishing, Budapest.

Valdés J, D Román, M Guiñez, L Rivera, T Morales, J Ávila \& P Cortes. 2010. Distribution and temporal variation of trace metal enrichment in surface sediments of San Jorge Bay, Chile. Environmental Monitoring and Assessment 167: 185-197.

Vargas G, L Ortlieb, J Pichon, J Bertaux \& M Pujos. 2004. Sedimentary facies and high resolution primary production inferences from laminated diatomaceous sediments off northern Chile (23 S). Marine Geology 211: 79-99.

Vélez A. 1981. Hábitat, alimentación y adaptaciones de Labrisomus philippii (Steindachener 1866) en el ecosistema del litoral de Palo de Buque. Iquique, Chile. Seminario Profesor de Estado en Biología y Ciencias, Universidad de Chile, Departamento de Ciencias Naturales, Iquique, Chile, $106 \mathrm{pp}$.

Vives I, J Grimalt, P Fernandez \& B Rosseland. 2004. Polycyclic aromatic hydrocarbons in fish from remote and high mountain lakes in Europe and Greenland. Science of the Total Environment 324: 67-77.

Zar JH. 1999. Biostatistical analysis, 663 pp. Prentice-Hall, Englewood Cliffs.

Received 13 October 2011 and accepted 7 March 2012 